\title{
Biomass of Microalgae via Root Under the Production of Yellow Passionfruit Seedlings
}

\author{
George Alves Dias ${ }^{1}$, Railene Hérica Carlos Rocha Araújo ${ }^{2}$, Wellington Guedes Alves ${ }^{3}$, \\ Agda Malany Forte de oliveira ${ }^{3}$, Diogenes Damarsio Andrade de Sousa ${ }^{3}$, José Franciraldo de Lima ${ }^{2}$, \\ Izabela de Moraes Santos ${ }^{1}$, Kalinny de Araújo Alves ${ }^{4}$, Diogenes Damarsio Andrade de Sousa ${ }^{3}$ \\ \& Josinaldo Lopes Araújo 2 \\ ${ }^{1}$ Unidade Acadêmica de Ciências Agrarias, Universidade Federal de Campina Grande, Pombal, PB, Brazil \\ ${ }^{2}$ Docente do Programa em Horticultura Tropical, Universidade Federal de Campina Grande, Pombal, PB, Brazil \\ ${ }^{3}$ Mestrando em Horticultura Tropical, Universidade Federal de Campina Grande, Pombal, PB, Brazil \\ ${ }^{4}$ Unidade Acadêmica de Tecnologia Agroalimentar, Universidade Federal de Campina Grande, Pombal, PB, \\ Brazil \\ Correspondence: George Alves Dias, Unidade Acadêmica de Ciências Agrarias (UAGRA), Universidade \\ Federal de Campina Grande (UFCG), Pombal, PB, Brazil. E-mail: george.alves.dias@hotmail.com
}

Received: December 7, 2018

Accepted: March 17, 2019 Online Published: May 15, 2019

doi:10.5539/jas.v11n6p105

URL: https://doi.org/10.5539/jas.v11n6p105

\begin{abstract}
Seedlings production is one of the most important stages of the production system and directly influences the performance of the plant in the field. In this sense, the present work aims to evaluate the use of biomass doses of Spirulina platensis and Scenedesmus sp. via root system on the production of yellow passion fruit seedlings. A greenhouse experiment was carried out using a randomized block design in a $2 \times 5$ factorial scheme (Spirulina platensis and Scenedesmus sp., at the doses $0.0 \%, 0.2 \%, 0.4 \%, 0.8 \%$ and $1 \% \mathrm{~m} / \mathrm{v}$ ), with four blocks and two experimental units per plot. At 60 days, leaf number, total seedling length, shoot diameter, root system length, shoot length, shoot and root fresh mass, dry mass, root dry mass and total chlorophyll were measured. Spirulina platensis showed superior performance compared to Scenedesmus sp., for the variables stem diameter, shoot length, fresh shoot mass, fresh root mass, dry shoot mass and root dry mass. The doses influenced the number of leaves, root fresh mass, root dry mass, shoot length and fresh shoot mass significantly. The best dose of microalga applied was $0.8 \%$ in passion fruit seedlings at 60 days.
\end{abstract}

Keywords: innovation, Passiflora edulis Sims, Scenedesmus sp., Spirulina platensis

\section{Introduction}

Brazil is the world's leading producer and consumer of passion fruit, occupying a prominent position in the world market. According to IBGE (2016) in the year 2016, the passion fruit yield in Brazil was 14.10 tons/ha with a production of more than 703 thousand tons in an area of more than 50 thousand ha, thus revealing the importance of the crop in the market. The fruits of the passion fruit tree have pleasant taste and aroma, excellent nutritional qualities being rich in minerals and vitamins, mainly A and C (Aguiar, Sperry, \& Junqueira, 2001).

Passionfruit consumption in Brazil is mainly in the form of juice, pulps, jellies, nectars, refreshments, ice cream and other culinary products. The bark is rich in soluble fibers, mainly pectin, and the flour can help in the reduction of cholesterol and blood glucose and slimming diets. The seeds are good sources of essential fatty acids and have vermifuge properties (Carvalho, 2015).

However, seedling production and crop establishment have problems, evidencing the need for planning and the adoption of technologies in the production. To obtain good quality seedlings, it is necessary to adopt techniques that improve the establishment, development and precocity in the seedling production. Echer et al. (2006) report that the production of passion fruit seedlings is one of the most important stages of the production system, directly influencing plant performance. 
Currently, there is a greater interest in natural products that stimulate the growth of plants. Microalgae are examples of natural products studied both as a source of food, as well as in agriculture, in the stages of seedling formation, development and production of plants (Mallmann \& Jahno, 2015; Marafon \& Simonett, 2016).

Spirulina platensis and Scenedesmus sp. have a high concentration of organic and inorganic substances in their commercial form that characterize it as a product with the potential to be used as a biofertilizer (Priyadarshani \& Rath, 2012). Therefore, the present work aimed to evaluate doses of Spirulina platensis and Scenedesmus sp., via root system on the production of yellow passion fruit seedlings.

\section{Material and Methods}

The experiment was conducted in a greenhouse at the Center for Science and Technology Agro-Food (CCTA) of the Federal University of Campina Grande (UFCG), Campus Pombal-PB, from September to December 2017. The municipality of Pombal is located at geographical coordinates $6^{\circ} 46^{\prime} 13^{\prime \prime}$ south latitude and $37^{\circ} 48^{\prime} 06^{\prime \prime}$ longitude west of Greenwich and altitude of $144 \mathrm{~m}$. The climate is classified as semi-arid ("AW" hot and humid) with annual average rainfall of $431.8 \mathrm{~mm}$ and temperature of $28^{\circ} \mathrm{C}$, according to Köppen.

We used a randomized complete blocks design $(\mathrm{RCB}$ ), in a factorial scheme $2 \times 5$ (Spirulina platensis and Scenedesmus sp. at the doses $0.0 \%, 0.2 \%, 0.4 \%, 0.8 \%$ and $1.0 \%$ ) constituting ten treatments, with four blocks and two plants per experimental unit. The yellow passion fruit seedlings were produced in a greenhouse in a $16 \times$ $20 \mathrm{~cm}$ container filled with a substrate formulated with soil, sand and cured bovine manure in the proportions of 3:2:1, pre-sterilized in an autoclave for one hour at $127^{\circ} \mathrm{C}$ and 1.5 atmosphere of pressure. The physical and chemical characteristics of the substrate are shown in (Table 1).

Table 1. Chemical and physical analysis of the substrate used to produce yellow passion fruit seedlings.

\begin{tabular}{|c|c|c|c|c|c|c|c|c|c|}
\hline \multirow[t]{3}{*}{ Chemical } & $\mathrm{pH}$ & CEas & $\mathrm{Ca}$ & $\mathrm{Mg}$ & $\mathrm{K}$ & $\mathrm{Sa}$ & \multirow{2}{*}{$\begin{array}{l}\mathrm{N} \\
\%\end{array}$} & \multirow{2}{*}{$\frac{\mathrm{P}}{\mathrm{mg} / 100 \mathrm{~g}}$} & \multirow{2}{*}{$\begin{array}{l}\text { M.O } \\
\%\end{array}$} \\
\hline & $\mathrm{H}_{2} \mathrm{O}$ & $\mathrm{dS} \mathrm{m}^{-1}$ & \multicolumn{4}{|c|}{------------- meq/100 g -------------- } & & & \\
\hline & 7.5 & 0.99 & 3.07 & 3.95 & 2.21 & 0.32 & 0.21 & 37.20 & 3.4 \\
\hline \multirow[t]{3}{*}{ Physical } & Sand & Silt & Clam & Class & Dens & & Porosity & \multicolumn{2}{|c|}{ Moisture } \\
\hline & \multicolumn{3}{|c|}{------------------ \% ---------------- } & & $\mathrm{g} / \mathrm{cm}$ & & \multicolumn{3}{|c|}{ |--------------------- \% ----------------. } \\
\hline & 67.09 & 27.40 & 5.51 & Sandy & 1.4 & & 47.95 & 0.45 & \\
\hline
\end{tabular}

Note. Soil and plant nutrition laboratory-LSNP, Pombal-PB. $\mathrm{pH}_{\mathrm{H} 2 \mathrm{O}}$ in water, $\mathrm{KCl}$ and $\mathrm{CaCl}_{2} \cdot 2 \mathrm{H}_{2} \mathrm{O}-\mathrm{Ratio} 1: 2.5 ; \mathrm{P}$, $\mathrm{K}$, Na: Mehlich-1 extractor; $\mathrm{Al}, \mathrm{Ca}, \mathrm{Mg}$ : extractor $\mathrm{KCl}-\mathrm{mol} / \mathrm{L}$; EC in water-ratio 1:2.5; CTC-Cation exchange capacity at $\mathrm{pH} 7.0$; V: base saturation. * Granulometry: by the Bouyoucos method, apparent density: $100 \mathrm{~mL}$ beaker method; real density: balloon method.

We used ISLA ${ }^{\circledR}$ brand seeds, sowing two seeds per container. The emergence occurred at 12 days after sowing, when the plants emitted the first pair of definitive leaves, we removed one seedling leaving only one plant per container. Sixteen days after emergence, we started the microalgae applications at seven day intervals, totaling five applications.

To obtain the solutions, we used biomass powders of microalgae purchased commercially, at Fazenda Tamanduá, in the municipality of Santa Terezinha-PB. The concentrations proposed in the treatments were weighed on analytical scale and diluted separately, the following amounts: $0 \%-0 \mathrm{~g}, 0.2 \%-1.6 \mathrm{~g}, 0.4 \%-3.2 \mathrm{~g}, 0.8 \%-6,4 \mathrm{~g}$ and 1\%-8 g Spirulina platensis biomass, and 0\%-0 g, 0.2\%-1.6 g, 0.4\%-3.2 g, 0.8\%-6.4 g 1\%-8 g of Scenedesmus sp. biomass, diluted in $800 \mathrm{ml}$ of tap water, under constant stirring until complete homogenization of the solution. Afterwards, $100 \mathrm{~mL}$ of the solution per plant was applied at the end of the afternoon, via fertirrigation. At 60 days after sowing (DAS), we conducted the morphological evaluations of plant growth. We estimated leaf numbers (LN), total length of seedling (TLS), plant height $(\mathrm{cm})(\mathrm{PH})$, stem diameter (mm) (SD), shoot length $(\mathrm{cm})(\mathrm{SL})$, root system length (RSL), shoot fresh mass and root fresh mass (g/plant) (SFM and RFM, respectively), shoot dry mass (g/plant) (SDM), root dry mass (g/plant) (RSM) and total chlorophyll (g/m²) (TCL).

The data were evaluated through analysis of variance by the $\mathrm{F}$ test at 1 and $5 \%$ probability levels, and the regression analysis for the doses and interaction between the microalgae and the doses studied with the aid of the SISVAR statistical software version 5.6 (Ferreira, 2011). 


\section{Results and Discussion}

According to Guimarães et al. (2015) microalgae are photosynthetic organisms that, with the combination of water and carbon dioxide from the atmospheric air, and sunlight produce diverse forms of energy, thus producing biomass, which is composed of polysaccharides, proteins, lipids and hydrocarbons. The composition of microalgae is highly variable, being affected by factors such as species, nutrients, temperature, photoperiod, salinity, carbon source and light intensity (Ramirez, 2013).

The results of the analysis of variance showed a significant interaction between the microalgae factors (A) and doses (D) for the SL variable. There was no significant interaction for the other variables. By smoothing the microalgae factor alone, a significant effect was observed for the SL, RFM and RDM, DC and SDM variables. For isolated factor doses, there was a significant effect for NF, RFM RDM, SL and SFM (Table 2).

Table 2. Summary of variance analysis for leaf numbers (LN), total length of seedling (TLS), plant height (PH), stem diameter (SD), shoot length (SL), root system length (RSL), shoot fresh mass (SFM), root fresh mass (RFM), shoot dry mass (SDM), root dry mass (RSM) and total chlorophyll (TCL) of yellow passion fruit seedlings produced with microalgae at different doses of application at 60 days of age

\begin{tabular}{|c|c|c|c|c|c|c|}
\hline \multirow{2}{*}{ Source of variation } & \multirow{2}{*}{ DF } & \multicolumn{5}{|c|}{ Mean Square } \\
\hline & & $\mathrm{LN}$ & TLS & SD & RSL & SL \\
\hline Microalgae (A) & 1 & $2.50^{\mathrm{ns}}$ & $6.04^{\mathrm{ns}}$ & $0.75^{*}$ & $21.46^{\mathrm{ns}}$ & $700.06^{* *}$ \\
\hline Dose (D) & 4 & $4.83 *$ & $494.12^{\mathrm{ns}}$ & $0.16^{\mathrm{ns}}$ & $6.75^{\mathrm{ns}}$ & $403.76^{* *}$ \\
\hline$A \times D$ & 4 & $0.32^{\mathrm{ns}}$ & $90.89^{\text {ns }}$ & $0.01^{\mathrm{ns}}$ & $6.36^{\mathrm{ns}}$ & $216.48^{* *}$ \\
\hline Block & 3 & $1.44^{\mathrm{ns}}$ & $159.29^{\mathrm{ns}}$ & $0.40^{\mathrm{ns}}$ & $4.36^{\mathrm{ns}}$ & $51.44^{\mathrm{ns}}$ \\
\hline Error & 27 & 1.21 & 284.74 & 0.16 & 10.48 & 51.74 \\
\hline $\mathrm{CV}(\%)$ & & 9.4 & 25.0 & 8.5 & 12.4 & 19.1 \\
\hline \multirow[t]{2}{*}{ General mean } & & 11.6 & 67.3 & 4.6 & 26.03 & 37.6 \\
\hline & GL & SFM & RSM & SDM & RDM & TCL \\
\hline Microalgae(A) & 1 & $63.35^{\mathrm{ns}}$ & $117.40^{* *}$ & $2.53^{*}$ & $3.11^{* *}$ & $0.16^{\mathrm{ns}}$ \\
\hline Dose (D) & 4 & $69.20^{* *}$ & $13.65^{*}$ & $0.88^{\mathrm{ns}}$ & $0.78^{*}$ & $0.83^{\mathrm{ns}}$ \\
\hline$A \times D$ & 4 & $4.65^{\mathrm{ns}}$ & $6.91^{\mathrm{ns}}$ & $0.37^{\mathrm{ns}}$ & $0.08^{\mathrm{ns}}$ & $1.11^{\mathrm{ns}}$ \\
\hline Block & 3 & $10.99^{\mathrm{ns}}$ & $12.78^{\mathrm{ns}}$ & $1.16^{\mathrm{ns}}$ & $0.64^{\mathrm{ns}}$ & $0.23^{\mathrm{ns}}$ \\
\hline Error & 27 & 15.23 & 4.77 & 0.48 & 0.28 & 0.41 \\
\hline $\mathrm{CV}(\%)$ & & 24.5 & 20.6 & 23.6 & 27.02 & 27.9 \\
\hline General mean & & 15.8 & 10.5 & 2.9 & 1.9 & 2.2 \\
\hline
\end{tabular}

Note. ${ }^{* *}$ significant at $1 \% ; *$ significant at $5 \% ;{ }^{\text {ns }}$ not significant at $5 \%$; CV: coefficient of variation.

The variable SD was statistically superior in the seedlings produced with Spirulina platensis via irrigation water than with Scenedesmus, whose averages were 4.82 and $4.55 \mathrm{~mm}$, respectively (Table 3). Greater viability was observed in the use of Spirulina platensis, due to the higher SD. We believe that $S$. platensis provided greater supply of nutrients for yellow passion fruit seedlings due to its composition of macronutrients, such as $\mathrm{Ca}, \mathrm{K}, \mathrm{P}$, $\mathrm{N}$ and micronutrients such as $\mathrm{Fe}, \mathrm{Cu}, \mathrm{Zn}, \mathrm{B}, \mathrm{Mn}, \mathrm{Co}$ (Marich et al., 2014).

We also verified similar behavior for the variable SL, RFM, SDM and RDM, where the best results occurred in seedlings produced with S. platensis, whose averages were $41.84 \mathrm{~cm}, 12.27 \mathrm{~g}, 3.19 \mathrm{~g}$ and $2.25 \mathrm{~g}$, respectively. There was no significant difference for shoot fresh mass between the prepared solutions based on microalgae (Table 3). The extracts based on algae may act as chelants, soil conditioners, improving the use of mineral nutrients by plants, soil structure and aeration, stimulating organ growth in the seedlings (Calvo, Nelson, \& Kloepper, 2014; Tarraf, Talaat, El-Sayed, \& Balbaa, 2015).

According to Tarraf et al. (2015), the use of Spirulina platensis in fenugreek plants provided significant increase in plant height, number of leaves, number of branches, fresh weight and dry weight of plants at the stage of vegetative growth and stage of flowering of plants, especially in plants treated with $5 \mathrm{~g} / \mathrm{L}$ of algae extracts in sandy and clayey soils. 
Table 3. Steam diameter (SD), shoot length (SL), shoot fresh mass (SFM), root fresh mass (RFM), shoot dry mass (SDM) and root dry mass (RDM) of yellow passion fruit seedlings produced with microalgae biomass at different application rates at 60 days after sowing

\begin{tabular}{lllllll}
\hline Algae species & SD & SL & SFM & RFM & SDM & RDM \\
\hline Spirulina platensis & $4.82 \mathrm{a}$ & $41.84 \mathrm{a}$ & $17.13 \mathrm{a}$ & $12.27 \mathrm{a}$ & $3.19 \mathrm{a}$ & $2.25 \mathrm{a}$ \\
Scenedesmus sp. & $4.55 \mathrm{~b}$ & $33.48 \mathrm{~b}$ & $14.61 \mathrm{a}$ & $8.85 \mathrm{~b}$ & $2.68 \mathrm{~b}$ & $1.69 \mathrm{~b}$
\end{tabular}

Note. Means followed by the same letter in the column do not differ from each other, by the Tukey test at the $5 \%$ probability level.

The highest leaf numbers (12.41) occurred using the highest dose of Spirulina platensis (Figure 1), with a mean of $14.34 \%$ higher than the control. The higher LN may be related to the higher concentration of the solution applied. These solutions present in their constitution nutrients such as nitrogen, phosphorus and potassium, essentials for plant growth, thus providing adequate nutrient levels for yellow passion fruit seedlings (Marich et al., 2014; Tarraf et al., 2015). According to Oliveira, Góes, Costa, and Silva (2011), the use of extracts based on Ascophyllum nodosum in the production of yellow passion fruit seedlings provided a significant increase in the number of leaves as the doses were increased up to the estimated value of $4.05 \mathrm{ml} / \mathrm{L}$ of the compound, above this value there was a decrease.

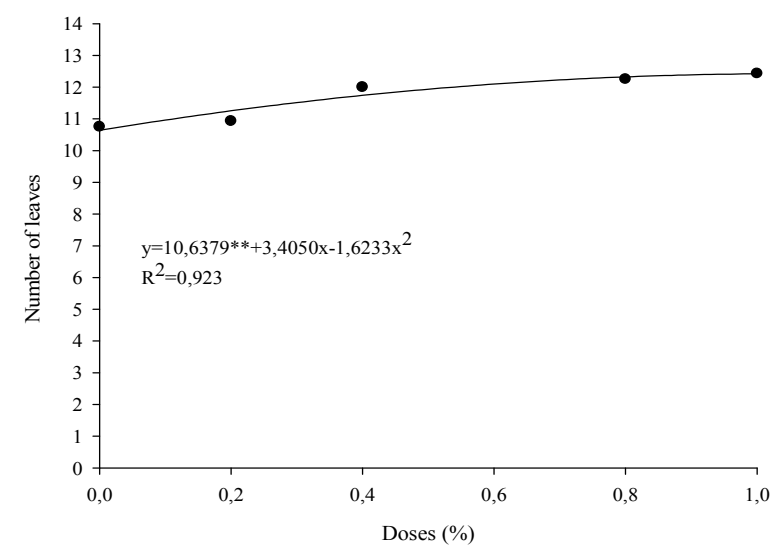

Figure 1. Number of leaves of yellow passion fruit, produced with microalgae biomass at different doses of application, at 60 days after sowing

Silva et al. (2015) observed in Annona glabra seedlings that the largest leaf numbers were obtained with the 2.0 $\mathrm{ml} / \mathrm{L}$ dose of Ascophyllum nodosum extract, and the use of larger doses showed a reduction in the expression of the growth variables evaluated. Authors associate the reduction of the phytotechnical characteristics to the condition of saline stress caused by the solutions when applied in higher doses.

The dose of $0.8 \%$ of the solution based on Scenedesmus increased $43.33 \%$ of SL concerning the control (Table 3 ). However, applications above $0.8 \%$, decreased $10.19 \%$ in SL. Possibly, the presence of high amounts of nutrients and the increase of EC in the Scenedesmus-based solution provided an inhibitory effect when concentrations above $0.8 \%$ were used.

Using increasing doses of Spirulina platensis we found that the $1.0 \%$ solution provided an increase in SL over the control of $43.17 \%$. The behavior observed in the seedlings through the effect of the applied doses showed that solutions prepared up to $1 \%$ of Spirulina platensis could be suitable for the cultivation of yellow passion fruit and promote positive changes in plant metabolism and physiology, improving their morphological characteristics uniformly.

Our result corroborates those of Rocha et al. (2017), that found that the use of Spirulina platensis at low concentrations $(1 \%)$ provides an improvement in the productive performance and influence on the water use efficiency (E/A) of papaya seedlings. According to Dias, Rocha, Araújo, Lima, and Guedes (2016) studying the application of Spirufert $\AA$, a product based on Spirulina platensis, $10 \mathrm{~g} \mathrm{~L}^{-1}$ applications provide a higher yield of 
eggplant fruits without influencing foliar N, P, K and Na. However, superior applications of the product favored the vegetative growth of the plants rather than the production.

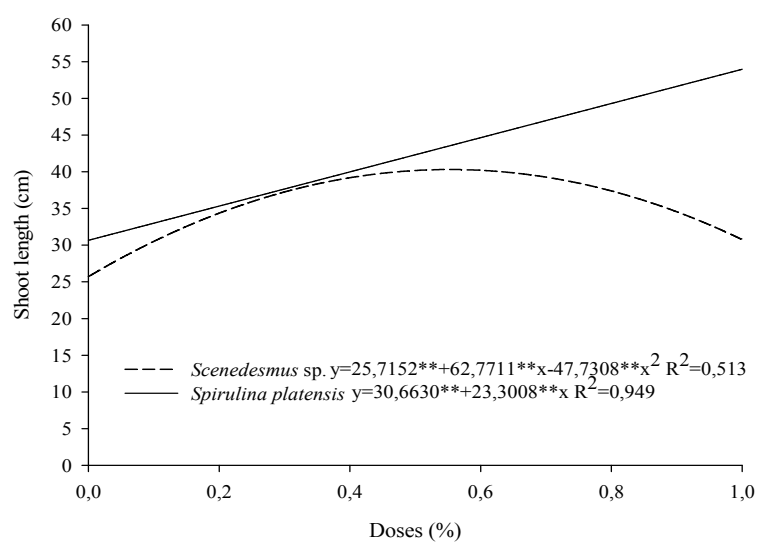

Figure 2. Interaction of the shoot length of yellow passion fruit, produced with microalgae biomass at different doses of application at 60 days after sowing

We verified at the application of $0.8 \%$ of the solutions based on microalgae an increase of $56.30 \%$ of the shoot length $(43.69 \mathrm{~cm})$ concerning the control. However, applications above $0.8 \%$ decreased the shoot length in $4.55 \%$ (Figure 3). It is possible that an inhibitory effect occurred when larger concentrations were used in solutions based on microalgae. Probably, this inhibitory effect was caused by the mineral nutrients, which are present in high concentration in the microalgae powder used for the research.

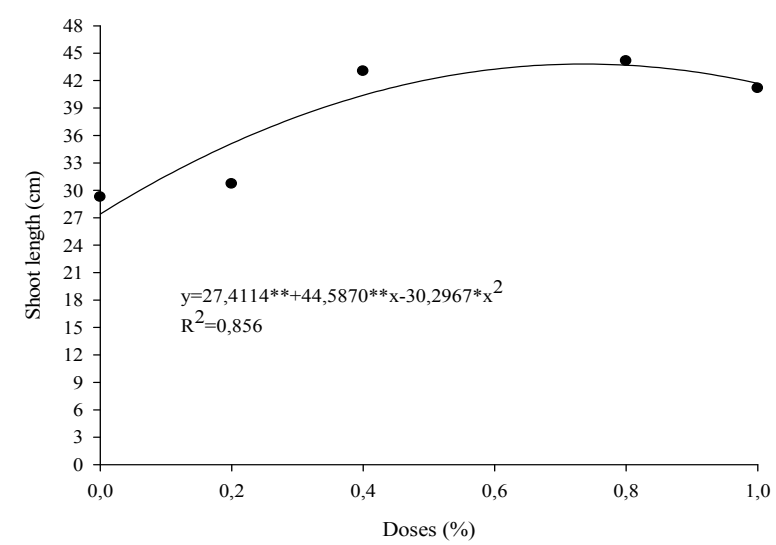

Figure 3. Shoot length of yellow passion fruit, produced with microalgae biomass at different doses of application at 60 days after sowing

Regarding to the shoot fresh mass, we found a positive effect of the organic matter supplied through the application of solutions based on microalgae. The lowest value $(12.58 \mathrm{~g})$ occurred in the absence of microalgae, while the increasing doses promoted a linear increase in the shoot fresh mass, an increase of $35.27 \%$ in relation to the control (Figure 4). Calvo et al. (2014) found that there was a gradual increase in plant growth, when the proportion of organic compounds in the soil was increased through algal applications. These results may be due to the high content of free amino acids of microalgae-based solutions, as well as their macronutrient and micronutrient contents, and the presence of some growth promoting substances directly absorbed by the seedlings (Babadzhanov et al., 2004; Aly \& Essawy, 2008). 


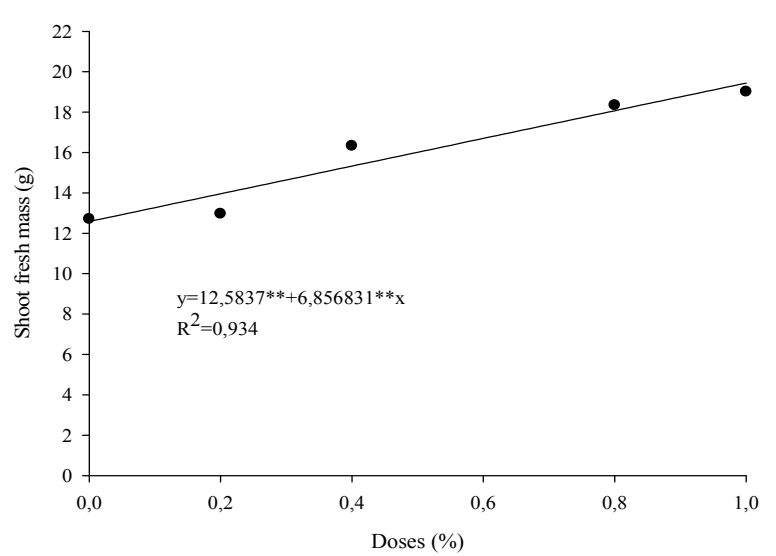

Figure 4. Shoot fresh mass of the yellow passion fruit seedlings, produced with microalgae biomass at different application rates at 60 days after sowing

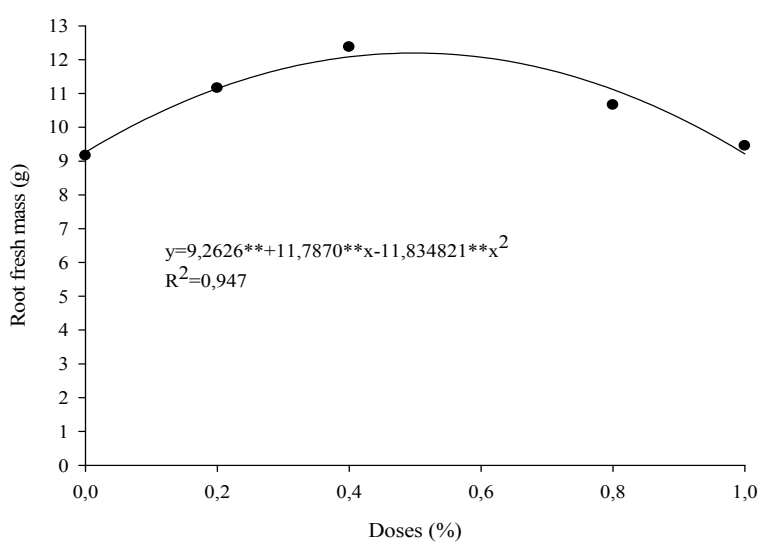

Figure 5. Root fresh mass of sour yellow passion fruit seedlings, produced with microalgae biomass at different application rates at 60 days after sowing

The application of $0.4 \%$ of solutions based on microalgae, resulted in an increase of $23.34 \%$ of root fresh mass in relation to the control. After the dose of $0.4 \%$ of microalgae there was a decrease of $23.74 \%$, this effect was accompanied by the root dry mass, in which there was also a decrease in this same dose of microalgae (Figure 4). These microalgae present important nutrients essential for the plant growth (nitrogen, phosphorus and potassium), favoring the accumulation of phytomass through the use of mineral nutrients by the plants and improving soil structure and aeration, stimulating the growth of the root system (Calvo et al., 2014; Marich et al., 2014). According to Silva et al. (2015), studying the application of Ascophyllum nodosum seaweed extracts in the production of araticum-do-brejo rootstocks, the use of doses above $4 \mathrm{ml} / \mathrm{L}$ negatively influences the vegetative growth of the plants, due to the solutions.

The root dry mass showed a quadratic behavior, and the maximum value for this variable $(2.22 \mathrm{~g})$ occurred at a dose of $0.8 \%$. This value is $30.17 \%$ higher than that observed in the yellow passion fruit seedlings produced without the use of the solutions. After this dose, a decrease in the root dry mass of $4.10 \%$ was observed (Figure 6). The use of algae and seaweed extracts act on soil properties as conditioners, increasing its moisture retention and favoring the growth of microorganisms in the soil (Calvo et al., 2014; Tarraf et al., 2015; Ribeiro et al., 2017). These characteristics may have contributed to the increase of the root area when using up to $0.8 \%$ of the solution based on microalgae. 


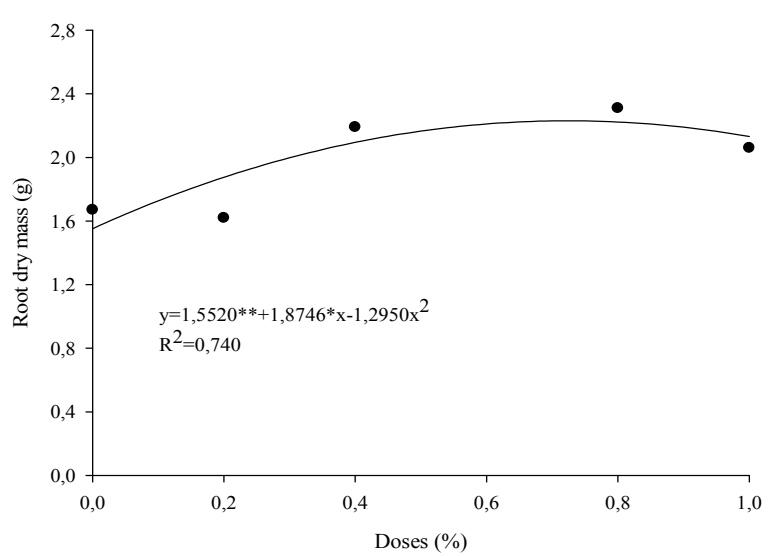

Figure 6. Root dry mass of the yellow passion fruit seedlings produced with microalgae biomass at different application rates at 60 days after sowing

The decrease in the dry mass gain of the root system may be due to the electrical conductivity of the solutions. When at the dose of $1 \%$ of the extract of Spirulina platensis and Scenedesmus sp. the electrical conductivity of the solutions were 0.88 and $1.37 \mathrm{dS} \mathrm{m}^{-1}$, respectively (Table 4). These effects may be due to the direct contact of root system with the osmotic environment, which possibly makes the seedlings more susceptible to the adverse conditions of the culture medium, thus influencing its dry mass gain of the root system (Silva et al., 2015).

\section{Conclusions}

Spirulina platensis provides greater phytomass accumulation in relation to Scenedesmos sp. in the production management of yellow passion fruit seedlings.

The best dose of algae applied was $0.8 \%$ for seedlings of yellow passion fruit at 60 days.

\section{References}

Aguiar, J. L. P., Sperry, S., \& Junqueira, N. T. V. (2001). A produção de maracujá na região do Cerrado: Caracterização socioeconomic (pp. 1-30). Circula Técnico 19. Ministério da Agricultura, Pecuária e Abastecimento. EMBRAPA, Brasília, DF.

Aly, M. S., \& Esawy, M. A. (2008). Evaluation of Spirulina platensis as Bio-stimulator for Organic Farming Systems. Journal of Genetic Engineering and Biotechnology, 6(2), 1-7.

Babadzhanov, A. S., Abdusamatova, N., Yusupova, F. M., Faizullaeva, N., Mezhlumyan, L. G., \& Malikova, M. K. (2004). Chemical composition of Spirulina platensis cultivated in Uzbekistan. Chemistry of Natural Compounds, 40(3), 276-279. https://doi.org/10.1023/B:CONC.0000039141.98247.e8

Calvo, P., Nelson, L., \& Kloepper, J. W. (2014). Agricultural uses of plant biostimulant. Plant and Soil, 385(1-2), 3-41. https://doi.org/10.1007/s11104-014-2131-8

Carvalho, S. L. C. (2015). Maracujá-amarelo: recomendações técnicas para cultivo no Paraná (p. 54). Londrina: IAPAR.

Dias, G. A., Rocha, R. H. C., Araújo, J. L., Lima, J. F., \& Guedes, W. A. (2016). Growth, yield, and postharvest quality in eggplant produced under different foliar fertilizer (Spirulina platensis) treatments. Semina: Ciências Agrárias, 37(6), 3893-3902. https://doi.org/10.5433/1679-0359.2016v37n6p3893

Echer, M. M., Guimarães, V. F., Krieser, C. R., Abucarma, V. M., Klein, J., Santos, L., \& Dallabrida, W. R. (2006). Uso de bioestimulante na formação de mudas de maracujazeiro amarelo. Semina: Ciências Agrárias, 27(3), 351-259. https://doi.org/10.5433/1679-0359.2006v27n3p351

Guimarães, B. S., Fernandes, M. S. M., Pessoa, J. D., Jovelino, J. R., \& França, K. B. (2015). Estudo da adaptação da microalga Scenedesmus sp. em meios modificados por sais. II Workshop Internacional Sobre Água no Semiárido Paraibano. Retrieved from https://editorarealize.com.br/revistas/aguanosemiarido/ trabalhos/trabalho_EV044_MD4_SA3_ID546_10092015152133.pdf

IBGE (Instituto Brasileiro de Geografia e Estatística). (2016). Produção agrícola municipal (Vol. 43, pp. 1-62). Rio de Janeiro, Brazil. Retrieved from https://biblioteca.ibge.gov.br/visualizacao/periodicos/66/pam_2016_ v43_br.pdf 
Mallmann, L. D., \& Jahno, V. D. (2015). As diversas SLicações de microalgas marinhas através dos saberes populares visando a utilização sustentável. Ambientalmente Sustentable, II(20), 1841-1856.

Manrich, A., Mermejo, B. C., Moraes, J. C., Oliveira, J. E., Mattoso, L. H. C., Marafon, F., \& Simonetti, A.P. M. M. (2016). Formas de SLicação e dosagens do extrato de microalgas na cultura da soja. Congresso Técnico Científico da Engenharia e da Agronomia CONTECC'. Retrieved from http://www.confea.org.br/ media/contecc2016/agronomia/formas\%20de $\% 20$ SLica $\% C 3 \% A 7 \% C 3 \% A 30 \% 20 \mathrm{e} \% 20$ dosagens $\% 20 \mathrm{do} \% 2$ 0extrato\%20de\%20microalgas\%20na\%20cultura\%20da\%20soja.pdf

Oliveira, A. C. (2013). Produção de biomassa de microalgas Scenedesmus sp. em efluente de bovinocultura biodigerido (Mestrado em Engenharia e Ciência dos Materiais, Universidade Federal do Paraná, Brazil).

Oliveira, L. A. A., Góes, G. B., Melo, I. G. C., Costa, M. E., \& Silva, R. M. (2011). Uso de extrato de algas (Ascophyllum nodosum) na produção de mudas de maracujazeiro-amarelo. Revista Verde, 6(2), 1-4.

Priyadarshani, I., \& Rath, B. (2012). Commercial and industrial applications of micro algae-A review. Journal of Algal Biomass Utln, 3(4), 89-100.

Ramirez, N. N. V. (2013). Estudo do crescimento da microalga Scenedesmus sp. em vinhaça (p. 109, Dissertação (Mestrado em Engenharia Química), Universidade Federal do Rio Grande do Sul, Brazil).

Ribeiro, R. F., Lobo, T. J., Cavalcante, Í. H. L., \& Tenreiro, D. D. L. (2017). Bioestimulante na produção de mudas de videira cv. Crimson Seedless. Scientia Agraria, 18(4), 36-42. https://doi.org/10.5380/rsa.v18i4. 50922

Rocha, R. H. C., Lima, J. F., Furtunato, T. C. S., Medeiros Junior, F. J., Guedes, W. A., \& Almeida, R. S. (2017). Biomass and physiology of papaya seedlings produced under leaf fertilization with Spirulina platensis. Cientifica, 45(4), 398-405. https://doi.org/10.15361/1984-5529.2017v45n4p398-405

Silva, C. C., Arrais, Í. G., Almeida, J. P., Dantas, L. L., Silva, F. S., \& Mendonça, V. (2015). Extrato da alga Ascophyllum nodosum (L.) Le Jolis na produção de porta-enxertos de Anonna glabra L. Revista de Ciências Agrárias, 39(2), 234-247. https://doi.org/10.19084/RCA15057

Tarraf, S. A., Talaat, I. M., El-Sayed, A. E. K. B., \& Balbaa, L. K. (2015). Influence of foliar application of algae extract and amino acids mixture on fenugreek plants in sandy and clay soils. Nusantara Bioscienc. https://doi.org/10.13057/nusbiosci/n070106

\section{Copyrights}

Copyright for this article is retained by the author(s), with first publication rights granted to the journal.

This is an open-access article distributed under the terms and conditions of the Creative Commons Attribution license (http://creativecommons.org/licenses/by/4.0/). 